Sports Humanities

\title{
Teaching futsal in schools: perspectives of teachers from Rio Grande do Sul and São Paulo state
}

\author{
Cesar Vieira Marques Filho ${ }^{1}$ (D), Luís Felipe Nogueira-Silva ${ }^{1}$ (D), Larissa Rafaela Gallati $^{2}$ (D), \\ Alcides José Scaglia ${ }^{2}$ D, Paulo Cesar Montagner ${ }^{1}$ \\ ${ }^{1}$ Universidade Estadual de Campinas, Faculdade de Educação Física, Campinas, SP, Brazil; \\ ${ }^{2}$ Universidade Estadual de Campinas, Faculdade de Ciências Aplicadas, Limeira, SP, Brazil.
}

Associate Editor: Sandro Carnicelli (D, University of the West of Scotland, Scotland, UK. E-mail:

Sandro.Carnicelli@uws.ac.uk.

\begin{abstract}
Aim: This study aimed to better understand the perceptions, actions, and interventions of Physical Education teachers at public state schools in the Rio Grande do Sul and São Paulo, regarding didactic-methodological spectra in futsal classes In Brazil, futsal is part of the team sport that must be presented in Physical Education classes, according to educational regulatory documents. Methods: Semi-structured interviews were conducted with eight teachers (three women and one man in each state), whose content was explored through a thematic analysis. Results: The results show a strong singularity of futsal as the content of Physical Education in schools and the relationship with its cultural impact. Different teaching concepts and methodologies used by teachers were identified, as well as a strong connection between experiences with futsal of students and the pedagogical practices adopted. Gender issues were highlighted, showing a contradiction between motivation to change the scenario and a school classes organization that promotes its maintenance. Conclusion: The study supports discussions about teacher actions epistemologically based on traditional teaching perspectives.
\end{abstract}

Keywords: physical education, teaching, sport, futsal.

\section{Introduction}

Futsal is among the most popular sports in Brazil and, consequently, has been analyzed in scientific studies addressing sociological, philosophical, physiological, and biomechanical aspects ${ }^{1}$. It has also been the focus of Sport Pedagogy investigations, a discipline that analyzes the processes of organization, systematization, application, and assessment of areas related to physical activity ${ }^{2}$. Pedagogical discussions about futsal involve understanding the "whys" and "hows" of teaching, experiencing, learning, and training futsal in its various contexts, among which Physical Education in schools can be inserted as a field that focuses on practices for the development of body and physical movements of human beings ${ }^{2,3}$. Futsal is a team sport advocated by the Basic National Curriculum (BNCC - Base Nacional Comum Curricular) as a body practice included at the invasion team sports unit, that should be offered from the third year of the basic education ${ }^{4}$.

Futsal teaching in schools, however, still involves didactic-methodological procedures that guide the teaching conduct, with an emphasis on deliberate practice and motor skill aquisition ${ }^{5}$. Relations among students, teachers, and the world are, therefore, based on the Cartesian paradigm, given the fragmentation of contents and the determinism in the interpretation of phenomena ${ }^{6}$. In this sense, Galatti et al. ${ }^{2}$ and Scaglia and Reverdito ${ }^{7}$ highlight the limitation of educational results due to sports learning and teaching practice supported by the Cartesian worldview. By proposing to discard these traditional pedagogical approaches in sports focused on teaching techniques without theoretical reflection, the authors started a movement called 'emerging trends in Sport Pedagogy.'

Supported by a paradigm shift of a systemic-complex focus, the emerging trends in Sport Pedagogy reveal the need for pedagogical intervention that favors an interrelationship and interdependence of physical, biological, psychological, social, and cultural phenomena ${ }^{7}$. These elements guide the implementation of methodologies for the interaction between the subjects involved in the teaching-learning process and the environment where they are inserted, as well as an understanding of the tactical dimensions of futsal based on the game phenomenon and its pedagogical intentions ${ }^{2}$.

Considering the scenario above and the opportunity to better reflect and understand several elements of our experience with futsal, in order to expand this discussion beyond our understanding of futsal practice in the school context and taking into account the plurality of pedagogi- 
cal approaches in the teaching-learning processes, we attempted to identify perspectives of the main mediators of this process - the teachers.

Therefore, from the emerging trends in Sports Pedagogy and the pursuance to overcome traditional pedagogical proposals, this study aimed to describe the perceptions, actions, and interventions of Physical Education teachers from public state schools in the Rio Grande do Sul (RS) and São Paulo (SP), regarding futsal teaching and assess aspects involved in the didactic-methodological spectra of the contexts in question. RS and SP are two of the most populous Brazilian states, gathering a relevant part of the 12 million futsal practitioners in the country ${ }^{1}$, mainly in urban centers and schools, whose spaces for the practice of physical education are, usually, multi-sport courts.

\section{Methods}

\section{Study design}

This qualitative study is characterized by its exploratory bias, enabling a deeper assessment of the objective reality and the subjectivity of individuals ${ }^{8}$ and an investigation of complex and situations in a given context $^{9}$. Our methodological approach was based on scientific interaction with the participants. We highlight that the life stories, sensitivity, and perception of the researchers were essential while searching and processing observations and responses of the elements related to the studied topic $^{10}$.

\section{Procedures and data collection}

This study was approved by the Research Ethics Committee of CAAE 20466519.7.0000.5404. Data were collected through semi-structured interviews, characterized by interviewer flexibility to guide the questions to interviewees ${ }^{11}$. The interview script questioned the personal relationship of teachers with futsal and their perspectives on teaching this sport in schools. The interviews were conducted during 2019, at locations and times chosen by the participants, audiotaped, and then transcribed for data analysis.

Each participant was contacted individually, by email, or by phone call to later schedule the interview. The first author contacted teachers of an inland city of RS from his old and other schools, all from the state system. The second author used the same procedure in the inland city of SP. The teachers were selected by convenience sampling, based on the knowledge of the authors, or recommended by residents. They were informed about the study procedures and objectives and were invited to participate. Those who agreed to participate received an informed consent form (ICF). They read and understood the ICF before accepting to participate. Each interview lasted around one hour. The teachers had to meet the following inclusion criteria:

1) Have taught Physical Education classes at public state schools for at least four years. This period considers that all teachers had at least one year as a full teacher after the internship period, which lasts three years in state schools in $\mathrm{RS}$ and $\mathrm{SP}^{12,13}$.

2) Be a teacher at $6 t^{\mathrm{h}}$ to $9^{\text {th }}$-grade students, to ensure Physical Education teacher with specific training in the area, considering that up to the 5 th grade, a single teacher can teach all disciplines and have a degree in different fields ${ }^{14}$.

\section{Participants}

Eight Physical Education teachers, male and female, were interviewed. The first author conducted four interviews in RS and the second author performed four interviews in SP. Table 1 shows the description of the participants. It is noteworthy that, from the sample involved and the methodological characteristics, the study did not intend to generalize the results to all teachers in SP and RS.

\section{Data analysis}

A thematic analysis was conducted for data analysis. This method identifies patterns in a set of data supporting data description, interpretation, and importance of the meanings. It has six stages: becoming familiar with data, generating codes, generating themes, reviewing themes, naming themes, and writing a report ${ }^{15}$. The process was performed jointly by the first two authors and reviewed by the other authors - three professors with a doctor's degree and vast experience and scientific publications about the theme. They also actively participated in the study discussions.

Table 1 - Characterization of participants.

\begin{tabular}{|c|c|c|c|c|c|c|c|c|c|}
\hline \multicolumn{5}{|c|}{ RS teachers } & \multicolumn{5}{|c|}{ SP teachers } \\
\hline Teacher & Age & Gender & Years as teacher & Number of student groups & Teacher & Age & Gender & Years as teacher & Number of student groups \\
\hline $\mathrm{T} 1$ & 31 & M & 4 & 8 & T5 & 38 & $\mathrm{~F}$ & 13 & 8 \\
\hline $\mathrm{T} 2$ & 60 & $\mathrm{~F}$ & 18 & 6 & T6 & 45 & $\mathrm{~F}$ & 19 & 11 \\
\hline $\mathrm{T} 3$ & 35 & $\mathrm{~F}$ & 13 & 10 & $\mathrm{~T} 7$ & 40 & $\mathrm{~F}$ & 7 & 12 \\
\hline $\mathrm{T} 4$ & 30 & $\mathrm{~F}$ & 5 & 10 & $\mathrm{~T} 8$ & 36 & $\mathrm{M}$ & 13 & 8 \\
\hline
\end{tabular}

RS: Rio Grande do Sul State; SP: Sao Paulo State. 
The thematic analysis conducted in this study was an inductive analysis, i.e., themes and groupings were not previously defined, but originated from the data analysis ${ }^{15}$. Four themes were obtained: 1) Futsal as content in schools; 2) Experience with futsal and effects on teaching practice; 3) Futsal teaching methodology, and 4) Differentiation between boys and girls.

\section{Results and discussion}

This study sought to understand the perspective of teachers regarding the elements that involve the teachinglearning process of futsal. However, in some moments, the teachers referred to soccer; in addition, the literature about this sport was used in this study. We recognize soccer and futsal as different sports; however, Cavichiolli et al. ${ }^{16}$ highlight these differences are more evident at high-performing levels, while strong similarities are found in the perspective of sports initiation, pedagogical aspects of the teaching-learning process, and leisure practice. Therefore, any reference to soccer has no impact on futsal assessment in our study.

\section{Theme 1: Futsal as content in schools}

When justifying futsal as content for Physical Education classes, all teachers mentioned some particularities, including futsal implementation because of the high interest of students (T1, T3, T4, T6, T8):

\footnotetext{
"It's what students like most, so I always give priority to what they like, not leaving aside the other parts of physical education, the other sports, but as they have that love for soccer and futsal, we usually give more emphasis so that they won't lose this feeling." (T4)

"They love futsal, it's something that often emerges in their lives because of soccer teams because they're fanatics [...] it's present in their lives since childhood they want to play soccer." (T3)
}

Futsal, besides being a highly appreciated content in the school context, is a popular phenomenon among men in Brazil. It is not restricted to Physical Education classes, as it is the favorite activity of boys in their free time in the school environment ${ }^{17}$. Girls, who are not encouraged to practice futsal as boys, still have a high interest in the sport $^{18}$.

Considering the high interest of students, several elements are associated with the importance of discussing futsal in schools, from the perspective of all teachers. According to them (T1, T3, T5, T6, T8), due to the engagement this sport provides, it is the preferred practice to apply other Physical Education contents:

\footnotetext{
"For me, the most important thing is that they value Physical Education and understand futsal is a part of it." (T5)

"With futsal, because of its popularity, its culture, it's easier, it's a pleasant sport to handle, it has good acceptance and, in general, everyone can play." (T6)
}

The speeches show the educational potential of futsal. According to Souza Junior and Darido ${ }^{19}$, futsal involves many social elements, such as the relationship among the practice of participation and performance, racial and social class issues, artistic manifestations, and popular culture. In this sense, the disassembly of a strictly competitive model allows exploring educational possibilities of futsal in schools, fighting the privilege of more skilled players ${ }^{20}$.

The singular look at futsal influences the frequency of this sport in Physical Education classes, with a pronounced difference between teachers from distinct states. In SP, the frequency of futsal in classes is linked with the state curriculum guidelines ${ }^{21}$, which requires such practice in the 6th grade. Although teachers seek to comply with this guideline, futsal has special attention as it is expanded to other grades and used as a preferred sport for interclass competitions.

\footnotetext{
"I think it's very important, but I don't think the frequency we use futsal in the classes is the ideal. The content we receive from the state doesn't show this sport beyond the 6th grade." (T5)

"Each grade - the 6th, the 7th, the 8th, and the 9th - at some point the students play futsal. So, I usually teach futsal for about one month. One month every year." (T8)
}

The teachers in RS did not mention the use of state curriculum guidelines. In this sense, we observed an individual organization among teachers and a strong relationship with the contextual demands of the schools where they work. Futsal has a broad scope, covering between half and one-third of the weekly classes of Physical Education, which can be justified by the fact that it is the preferred content of students and that such high frequency contributes to a better acceptance of other sports which also makes it the first to be taught.

\footnotetext{
"I do it this way, I teach another sport and futsal, then another sport and futsal. For example, volleyball and futsal, then handball and soccer. So, we have two classes, three classes in a week. In two classes, I teach volleyball for example and soccer or vice versa, I take turns, but soccer has to be included, so they produce more in the classes." (T4)

"Futsal, we start with it $[\ldots]$ because all students love it, so I start with it so I can finish soon because, otherwise, they don't want to practice another sport." (T4)
}

Futsal is practiced more often due to its closeness to the life of students and because it is a step to the practice of other sports that may seem less attractive to them. Diniz, Rodrigues, and Darido ${ }^{22}$ highlight the resistance found among students in a situation of reducing time dedicated to futsal in Physical Education classes.

Distinct approaches are observed regarding the volume of futsal content among teachers from SP and RS. By not using the curriculum guidelines, teachers seek to better meet student demands. We can perceive a search for meaningful learning ${ }^{23}$, in which prior knowledge of stu- 
dents is the starting point, for instance, their broad experience with futsal. Moreira ${ }^{24}$ shows such significant learning takes place when new information acquires meaning through interaction with pre-existing relevant aspects in the individuality of students. Based on student appreciation of this sport, the teachers in RS perceive futsal as an optimization process and step to teach other content, in agreement with the perspective that learning is linked with motivation, interest, and the ability to share experiences by the students ${ }^{25}$.

However, Araújo, Rocha, and Bossle ${ }^{26}$ show some hegemony of content focused on soccer to the detriment of other sports in the school context, strengthening a sports monoculture in Brazilian society. This context can impair the diversity and scope of class content ${ }^{27}$. In addition to the importance of students experiencing other modalities, this diversification is indicated in the BNCC. Then, considering the above, we propose to assess futsal as a highly appreciated content in schools due to its role in Brazilian sports culture versus the importance of ensuring student access to other types of sports.

\section{Theme 2: Experience with futsal and effects on teaching practice}

Experiences as regular futsal players or not before becoming a teacher supported the pedagogical conduct of teachers. The difference in the number of hours of futsal practice between male teachers (T1, T8) and female teachers (T2, T3, T4, 75, T6, T7), however, did not seem to cause disparities in the teacher actions, characterized by replication of situations experienced when they were students. Then, among male teachers from both states, the practice of futsal before becoming a teacher proved to be common:

"I always liked soccer, futsal very much; we even had a group of friends; we used to meet and play." (T1)

"I always practiced, I always participated in the school team, for competitions in the school and the city." (T4)

Female teachers (T2, T3, 75, T6, T7) however, highlighted little contact they had with sports as students in Physical Education classes. The relationship with futsal, especially in the school period, was not encouraged because of the idea that such practice was not for girls:

\footnotetext{
"In those days, soccer was not for girls [...] at school, futsal was never taught to girls." (T2)

"A girl playing soccer was not a good thing. I lived in a context where soccer or futsal was only taught to boys and volleyball was taught to girls." (T5)
}

All of them (T2, T3, 75, T6, T7) admitted that they were victims of gender prejudice in the practice of soccer and futsal. Although they disagreed with the organization and systematization of Physical Education classes, which limited their experience with soccer and futsal, they reproduced signs of such context in their pedagogical practice.
Even though they did not restrain the practice of futsal among girls, female teachers reported they prevent the activities related to the sport with the boys, arguing that separating the skill levels of the game is necessary so that students can practice it without moral embarrassment. One more time, a unique treatment in relation to futsal classes is evident, as the separation of boys and girls is not seen in the other curriculum components of basic education, nor is it supported by educational legislation.

"When I teach soccer, I separate boys from girls. Boys don't like
to play with girls, they're kind of aggressive, you know. But some
girls insist and end up playing, but only the very good ones." (T5)
"With boys, the challenge is not to leave the game control with
the most skilled ones and try to ensure a more collective sense.
Some of them think they know everything, they are 'ball hogs' so
you can't let them play with the girls." (T7)

The reproduction of methods and didactic approaches experienced as students in Physical Education classes was evident (T1, T2, T3, T4, T8):

\footnotetext{
"The methodology is more or less the same: warm-up, perform an activity, a technical or tactical activity, depending on the age group, and then, practice, a lot of practice, more or less the same style." (T1)

"I often make correlations with it, there are some similarities between what I do and what was done when I was a student. The games, the fundamentals that were practiced (...) today I use many activities that I used to practice." (T3)
}

We can say the pedagogical conduct of Physical Education classes, whose content includes futsal, replicates some behaviors of teachers from their school time. The teaching practice of study participants, based on empiria, agrees with what Becker $^{28}$ calls common-sense epistemology, in line with the Cartesian paradigm ${ }^{6}$. This thinking, in a positivist and behavioral sense, influences the teaching approach, as actions and interventions are reedited from what was once practiced and supposedly successful - and not based on real demands of the school context - linked with behaviors of other peers and their own background $^{29}$.

\section{Theme 3: Futsal teaching methodology}

Strong connection with empiricism, as a theory of knowledge, observed in the relationship between experience as futsal player and teacher behavior, are also seen in the way three of RS teachers (T1, T2, T4) present their teaching methodological conceptions. They adopt pedagogical approaches that, in the sports context, are associated with a technicist perspective, as they are focused on the development of stereotyped behaviors and actions to generate short-term learning responses, discarding a teaching process that considers student individuality ${ }^{7}$.

\footnotetext{
"I give a very high technical importance, I think it's very impor$\operatorname{tant}[\ldots]$ it is no use pretending that I've learned a movement, you see, I think the tactic comes after you have good technical performance." (T2)
} 
"I often use few games. I use many repetitions of fundamentals. One facing the other, exchanging passes, for example, the technical performance actually." (T4)

A priori, every game is understood from the sum of parties and, therefore, each element of the game must be fragmented and developed separately ${ }^{2}$. Then, the technical performance, as the motor execution of the game fundamentals, must be the first aspect to be practiced, because, in order to play, a player must first master the technical movements of the sport ${ }^{7}$. Technicism cannot be understood as the teaching of a technique, but rather as a didactic-methodological action guided by the precepts of technicists (pedagogical theory) and empiricists (theory of knowledge $)^{7}$.

Other teachers were opposed to technicist pedagogical conduct, such as T3 and T7. When reporting how they understand the essence of the teaching processes of futsal, the teachers from both states deny game elements developed separately or considered as a game prerequisite:

\footnotetext{
"I practice games more often, more tactics than technical elements, with a focus on playing. They play, they play games with fewer members." (T3)

"When students come to school, $[\ldots]$ they don't want the technical part of the specialization, [...] I think the best way is to practice through games, I feel that then sometimes I score goal by goal when I want to address a different topic." (T7)
}

The statements above show a teaching process adjacent to the global-functional method. Game is seen as a complex system, in which the whole is not limited to the sum of the parts ${ }^{2}$. A pedagogical sense is acquired as the structural and functional elements are considered in the integrative logic of the game ${ }^{29}$. However, separating tactics from technical elements is opposed to the global-functional method - in it, the game is an inseparable whole, in which the technical element only makes sense if linked with a tactical decision ${ }^{30}$.

The other teachers of SP also presented the third panorama of teaching conception. Although they avoid activities based on technicist assumptions, using free games is not rigorous regarding its pedagogical intention:

\footnotetext{
"I like to leave them very free to play, they create a crowd around the ball, they don't have much sense of space, it's fun, they kick whatever is ahead." (T6)

"It has to be a game situation (...), so it is a matter of teaching the game itself." (T8)
}

Sports learning is at risk of being overlapped by the dissemination of relevant values to social life, in addition to a concern to offer recreational connotation to the class context, which is typical of the progressive education thought. Even though the affective dimension and the nonfragmentation of the game into parts seem included, futsal teaching is masked by minimum didactic intervention in the activities $^{31,32}$.
"They already master the technical part, but they need to be humble, companionship and many of them develop it." (T2)

"A physical education teacher can open many doors for the students and can get them away from a lot of things they shouldn't do, like drugs, violence; we can bring students to us and motivate them to (...) the good things that sport offers." (T4)

Regarding class structuring, the difference between teachers from the two states was marked by a mandatory fulfillment of certain requirements among SP teachers, and more flexibly, among RS teachers as well. Although São Paulo teachers do not strictly follow the curricular content of the teacher's book issued by local Education Divisions ${ }^{21}$, the speeches clearly show a direction in their modus operandi:

\footnotetext{
"Do I follow the teacher's book completely? Not exactly, I adapt some things. Content is mandatory, what I can do? I try to do that my own way." (T5)

"You won't find much difference if you interview other teachers. They will show you the teacher's book, tell you they apply its content because we are obliged to. Of course, each one uses it somehow, but with particularities, we have to do what's in it." (T6)
}

When evaluating the way teachers conduct the classes, technicist-oriented teachers (T1, T2, T4) prioritized the specificity of the fundamentals of the game divided by stages. Teachers who support the application of games (T3 and T7) presented contextual tasks and reduced games, while those who value free play $(\mathrm{T} 5, \mathrm{~T} 6, \mathrm{~T} 8)$ prioritize this type of activity. Then, an epistemological coherence was observed in the relationship between theory and practice in the development of classes, even though the reservation was made that the teaching models and their methods must be understood from the relationship with the teacher's pedagogical objective.

\footnotetext{
"I work a lot with a circuit of activities, that's where they have to run between cones, adjust a pass at a fixed point, for example sometimes at the bar and crossbar, we use tools in the bar, and they have to hit them." (T1)

"They play games, play reduced games, games with fewer members [...] I practice games more often, more tactics than technical elements, with a focus on playing." (T3)

"It's just the game. I use participation a lot." (T5)
}

\section{Theme 4: Differentiation between boys and girls}

Differences were observed in futsal teaching processes between boys and girls. The division of classes by gender was identified in the speech of five teachers (T1, $\mathrm{T} 2, \mathrm{~T} 3, \mathrm{~T} 6, \mathrm{~T} 8$ ), that is, $75 \%$ of teachers from RS and $50 \%$ from SP make this option. Even teachers with mixed classes highlighted disparities in the pedagogical treatment. According to the teachers, the level of skills is the most evident element between boys and girls and acts as a driver of differentiation when handling these audiences.

"One thing that also facilitates our work is separating boys from girls, because they have different skills, right?" (T1) 
"The girls have no skills, right? That's what I do: I divide the group, the boys go first, right? And the girls must start from the beginning, but the boys don't." (T3)

In the development of futsal, separating boys from girls is a characteristic of pedagogical and epistemological traditionalism in Physical Education in Brazil. This division maintains the models sexually typified by the family and society, reinforcing the idea that boys have a better aptitude for futsal ${ }^{33}$. Regarding the levels of skill, the teachers justified the contrast of previous knowledge and experience owned by boys concerning girls in terms of practice outside the school environment. They pointed that most boys are already futsal players, while many girls will have their first contact with this sport in Physical Education classes. It is noteworthy that this division is also carried out by teachers who defend a technicist perspective, although this will direct a more individualized view to the students' technique development.

\footnotetext{
"When a girl is born, what will she do? Play with her dolls. And the boy? He will play with his ball! So, girls already have this idea that they are not suitable for this sport."(T5)

"I feel girls don't have anyone who encourages them before they reach school age. Some girls say their mothers get angry if they play futsal. I have a 7-year-old son who is not really interested in playing football, but he certainly kicks a ball better than a girl.

Why? Because he has already experienced that." (T7)
}

Among the historical elements that attest futsal as a male sport, the most representative element refers to the prohibition of women's practice of this sport until the 1980s, even with an increasing insertion of girls and women in this sport since then ${ }^{34}$. Although many women teachers were school students during this historical period, it is common for them to reproduce this format as Physical Education teachers. Mariano and Altmann ${ }^{35}$ indicate a gap in the under-graduation courses in Physical Education when dealing with these issues and highlight the importance of teacher education programs that makes it possible to reconstruct the pedagogical practices experienced as students. We identified concerns of some teachers regarding this perspective:

\footnotetext{
"As I didn't have the opportunity to play when I was a girl, I think it's very important to demystify it as a sport only for boys." (T2)

"In the beginning, girls don't want to play football, not all of them, right? But most of them start to like it as they start playing. When they interact and learn, it gets better." (T4)
}

The role of teachers in presenting fair possibilities for futsal practice for all genders has been supported by studies in the literature. Teacher intervention has encouraged the engagement of girls with the sport ${ }^{35}$, contributing to the deconstruction of prejudices ${ }^{36}$, and has played a decisive influence on the career of women who have achieved high performance as soccer/futsal athletes ${ }^{37}$. It is also important that teachers positively promote this encouragement. Like T4, the teacher values the game's interactions to awaken the girls' interest in the practice, which is contradictory concerning their technical methodological approach. However, school is only one of the potential environments that can encourage girls to practice futsal, other contexts and family support are also important $^{37}$.

\section{Conclusion}

The study perceived a strong singularity of futsal as the content of Physical Education. The cultural impact of this sport is seen in the interest of students and, therefore, futsal receives special treatment. Regarding the application of teaching-learning procedures, a plurality of teaching concepts and different methodologies could be observed, which include game control and fragmentation into parts, a more systemic understanding, and appreciation of tactical elements, as well as free play and minimal teacher intervention.

The experience with futsal has influenced the performance of teachers interviewed in this investigation. Many influences of the prior student experience are reflected in their pedagogical practices. The elements identified include gender issues. Although the teachers demonstrate the desire to promote greater equity in access to quality futsal for boys and girls, many aspects in the structuring of classes reinforce an opposite move. This study also provides new light on the teachers Physical Education Degree, which may raise questions about how this process helps to overcome traditional teaching models and how teachers, throughout under-graduation, can build significant knowledge about the pedagogical practice related to Brazilian educational legislation. Furthermore, in addition to the education process, this study reveals complaints regarding the modus operandi of School Physical Education, based on the structural and curricular conditions offered in the research contexts. Despite the good intentions of professionals and the epistemological contradictions inherent in the pedagogical action in the field of physical education and sports teaching, there is a considerable distance between discourses and the realization of disruptive practices. What we found were more traditional teaching reports, like futsal being a dominant content in Physical Education classes, the methodologies approach in teaching this sport, as well as the treatment distinction - still reinforced - between boys and girls. Taking into account the particularities of the observed contexts, this study identified the need for reflection about pedagogical practices focused on futsal in schools in order to minimize the didactic-methodological contradictions identified, discussing and questioning teacher actions epistemologically based on traditional teaching perspectives. 


\section{Acknowledgments}

This study was supported by Coordenação de Aperfeiçoamento de Pessoal de Nível Superior (CAPES), Brazil.

\section{References}

1. Marques Filho CV, Folhas GS, Galatti LR, Santana WC, Montagner, PC. A produção científica sobre treinadores de futsal no Brasil. Pensar Prát. 2021;23:e64620. doi

2. Galatti, LR, Reverdito RS, Scaglia AJ, Paes RR, Seoane AM. Pedagogia do esporte: tensão na ciência e no ensino dos jogos esportes coletivos. Rev Educ Fís UEM. 2014;25 (1):153-62. doi.

3. Damo, AS. Monopólio estético e diversidade configuracional no futebol brasileiro. Movimento. 2003;9(2):12956. doi

4. BNCC. Base Nacional Curricular Comum. Brasília: Ministério da Educação; 2018.

5. Costa LCA, Nascimento JV. O ensino da técnica e da tática: novas abordagens metodológicas. Rev Educ Fís UEM. 2010;15(2):49-56.

6. Kuhn T. A estrutura das revoluções científicas. $13^{\mathrm{a}}$ ed. São Paulo: Perspectiva; 2017.

7. Scaglia AJ; Reverdito RS. Perspectivas pedagógicas do esporte no século XXI. In: Educação física e esporte no século XXI. Campinas, Papirus; 2016. p. 45-58.

8. Cachoeira NR, Fiamoncini L. Educação somática e dança na consciência corporal. Pensar Prát. 2018;21(3):564-76. doi

9. Tahara AK, Darido SC. Diagnóstico sobre a abordagem das práticas corporais de aventura em aulas de educação física escolar em Ilhéus/BA. Movimento. 2017;24(3):973-86. doi

10. Thomas JR, Nelson JK, Silverman SJ. Métodos de pesquisa em atividade física. 5. ed. Porto Alegre, Artmed; 2007.

11. Marconi MA; Lakatos EM. Técnicas de pesquisa: planejamento e execução de pesquisas; amostragens e técnicas de pesquisa; elaboração, análise e interpretação de dados. 8 ed. São Paulo, Atlas; 2017.

12. São Paulo. Secretaria de Educação. Resolução SE n. 66, Decreto 52.344. Available from: http://www.educacao.sp. gov.br/lise/sislegis/detresol.asp?strAto $=200811070079$ [Accessed 15th July 2020].

13. Rio Grande do Sul. Assembleia Legislativa. Decreto n. 50.449 de 1 de julho de 2013. Available from: http:// www.al.rs.gov.br/filerepository/repLegis/arquivos/DEC\% 2050.449.pdf [Accessed 15th June 2020].

14. Brasil. Ministério da Educação. Secretaria de Educação Básica. Diretrizes Curriculares Nacionais Gerais da Educação Básica. Brasília, Ministério da Educação; 2013.

15. Braun V, Clarke V, Weate P. Using thematic analysis in sport and exercise research. In: Routledge handbook of qualitative research in sport and exercise. Abingdon, Routledge; 2016. p. 191-205.

16. Cavichiolli FR, Cheluchinhak AB, Capraro AM, Marchi Junior W, Mezzadri FM. O processo de formação do atleta de futsal e futebol: análise etnográfica. Rev Bras Educ Fís Esp. 2011;25(4):631-47.
17. Pereira SAM.; Mourão L. Identificações de gênero: jogando e brincando em universos divididos. Motriz: J. Phys. Ed. 2005;11(3):205-10.

18. Castro PA, Sousa DFVO, Cruz MMS, Medeiros AGA. Tematizando o futsal nas aulas de educação física: quando meninos e meninas trocam passes. Hor Rev Educ. 2016;4 (8):225-34

19. Souza Junior OM, Darido SC. Refletindo sobre a tematização do futebol na educação física escolar. Motriz: J Phys Ed. 2010;16(4):920-30. doi

20. Montagner, PC, Scaglia AJ. Pedagogia da competição: teoria e proposta de sistematização nas escolas de esportes. In: Pedagogia do esporte: aspectos conceituais da competição e estudos aplicados. São Paulo, Phorte Editora; 2013. p. 193-216.

21. São Paulo. Secretaria da Educação. Caderno do professor. Available from: https://www.educacao.sp.gov.br/cadernoprofessor. [Accessed 20th July 2020].

22. Diniz, IKS, Rodrigues, HA, Darido, SC. Os usos da mídia em aulas de educação física escolar: possibilidades e dificuldades. Movimento. 2012;18(3):183-202. doi

23. Tavares R. Aprendizagem significativa, codificação dual e objetos de aprendizagem. Br J Comp Ed. 2010;8(2):1-16. doi

24. Moreira MA. A teoria da aprendizagem significativa e sua implementação em sala de aula. Brasília, Editora da Universidade de Brasília; 2006.

25. Santos JCF. Aprendizagem significativa: modalidades de aprendizagem e o papel do professor. Porto Alegre, Mediação; 2008.

26. Araújo SN, Rocha LO, Bossle F. Sobre a monocultura esportiva no ensino da educação física na escola. Pensar Prát. 2018; 21(4):842-35. doi

27. Rufino LGB, Souza Neto S. Saberes docentes e formação de professores de educação física: análise da Base Nacional Comum Curricular (BNCC) na perspectiva da profissionalização do ensino. Pensar Prát. 2016;28(48)42-60. doi

28. Becker F. Epistemologia do professor: o cotidiano da escola. $13^{\mathrm{a}}$ ed. Petrópolis, Vozes; 2008.

29. Hirama LK, Joaquim CS, Costa RR, Montagner PC. Propostas interacionistas em pedagogia do esporte: aproximações e características. Conexões. 2014;12(4)51-68. doi

30. Aquino RT, Marques RR, Gonçalvez LGC, Vieira LHP, Bedo BLS, Moraes C, et al. Proposta de sistematização de ensino do futebol baseada em jogos: desenvolvimento do conhecimento tático em jogadores com 10 e 11 anos de idade. Motricidade. 2015;11(2):115-28. doi

31. Soares CL. Educação física: raízes europeias e Brasil. 5 ed. Campinas, Autores Associados; 2012.

32. Saviani D. História das ideias pedagógicas no Brasil. 4. ed. Campinas, Autores Associados; 2013.

33. Souza Junior OM, Darido SC. A prática do futebol feminino no ensino fundamental. Motriz: J Phys Ed. 2002;8(1):1-9. doi

34. Castellani LF. Educação física no Brasil: a história que não se conta. 19 ed. São Paulo, Papirus; 2013.

35. Mariano M, Altmann H. Educação física na educação infantil: educando crianças ou meninos e meninas? Cadernos Pagu. 2016;(46):411-38. doi 
36. Santos PSM, Hirota VB. Futsal na educação física escolar: a participação das meninas. Lec Edu Fís Dep. 2012;17 (167):1-1.

37. Martins MZ, Reis HHB, Castellani RM, Santana WC, Altmann $\mathrm{H}$. Entre o amadorismo, a profissionalização e carreira dupla: o futsal feminino de elite sul-americano. Rev Bras Cie Mov. 2018;26(1):143-55. doi.

\section{Corresponding author}

Cesar Vieira Marques Filho, Universidade Estadual de Campinas, Faculdade de Educação Física, Campinas, SP,
Brazil.

E-mail: cesarvmf@hotmail.com.

Manuscript received on July 17, 2021

Manuscript accepted on October 13, 2021

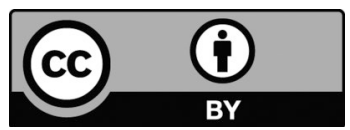

Motriz. The Journal of Physical Education. UNESP. Rio Claro, SP, Brazil - eISSN: 1980-6574 - under a license Creative Commons - Version 4.0 